\title{
Influence of porcine genotype on the abundance of thyroid hormones and leptin in sow milk and its impact on growth, metabolism and expression of key adipose tissue genes in offspring
}

\author{
Alison Mostyn, Sylvain Sebert, Jennie C Litten ${ }^{1}$, Katharine S Perkins ${ }^{1}$, John Laws ${ }^{1}$, Michael E Symonds \\ and Lynne Clarke ${ }^{1}$ \\ Institute of Clinical Research, Centre for Reproduction and Early Life, University Hospital, Nottingham NG7 2UH, UK \\ ${ }^{1}$ Department of Agricultural Sciences, Imperial College London, Wye Campus, Ashford, Kent TN25 5AH, UK \\ (Requests for offprints should be addressed to A Mostyn who is now at School of Nursing, Queen's Medical Centre, University Hospital, Nottingham NG7 2HA, UK; \\ Email: alison.mostyn@nottingham.ac.uk)
}

\begin{abstract}
Neonatal mortality is greater in commercial porcine genotypes, compared with the ancient Meishan breed that rapidly lay down adipose tissue; this may be related to hormones, such as triiodothyronine $\left(\mathrm{T}_{3}\right)$ or leptin. Leptin is present in maternal milk; however, the extent to which this supply provides the neonate with leptin is unknown, but may play a role in growth and development. We investigated whether thyroid hormones and leptin concentrations in maternal milk differed between genotypes; and whether this influenced piglet concentrations or expression of genes involved in adipose tissue regulation. Eight Meishan and six commercial sows were entered into the study and milk samples from the day of parturition to day 4 postpartum was taken daily. The median birth weight piglet in each litter had a daily venous blood sample taken and was euthanised on day 4 . Gene expressions of IGF-I, IGF-binding protein 3 (IGFBP3 ), peroxisome proliferators activated receptor (PPAR) $\gamma$ and glucocorticoid receptor (GR) were measured in adipose tissue
\end{abstract}

using real-time PCR. $\mathrm{T}_{3}$ was increased in Meishan milk, but not in piglet plasma. Milk thyroxine was similar between breeds but commercial piglet levels were significantly higher. Leptin was higher in commercial sow milk throughout the study. Milk leptin was strongly correlated to plasma leptin during the first postnatal days and also to organ and body weight in Meishan piglets that also had significantly higher expression of GR, but not IGF-I, IGFBP-3 or PPAR $\gamma$. In conclusion, we have found a significant disparity in the provision of thyroid hormones in Meishan and commercial sow's milk. These changes are not always translated to plasma concentrations of hormone in the piglet. Leptin appears to have a stronger role in growth and development in the Meishan genotype compared with commercial; along with the increased GR expression, this may also represent a potential mechanism behind the rapid accumulation of adipose tissue in Meishan piglets.

Journal of Endocrinology (2006) 190, 631-639

\section{Introduction}

It is well documented that Meishan, an ancient oriental breed of pig, have significantly lower neonatal mortality rates than commercial breeds (i.e. meat producing; Le Dividich et al. 1991), despite being smaller at birth and having larger litters (Le Dividich et al. 1991, Herpin et al. 1993). Meishan sows are obese and produce milk with a higher fat content than commercial sows (Alston-Mills et al. 2000), which may be one factor responsible for the apparent resistance to hypoglycaemia and hypothermia observed in their piglets. Our recent studies have established that there is a significant disparity in the expression of the mitochondrial uncoupling proteins (UCP) 2 and 3 in adipose tissue and skeletal muscle between these breeds, as well as significantly higher plasma triiodothyronine $\left(\mathrm{T}_{3}\right)$ in the commercial breed on the first day of life, but this does not appear to improve their ability to thermoregulate (Mostyn et al. 2004).

Adequate provision of milk to newborn piglets is critical in ensuring provision of nutrients, not only to negate hypoglycaemia, but also to provide energy for temperature regulation. Colostrum also supplies the newborn piglet with a source of immunoglobulins (Norcross 1982). Sow milk is known to contain a number of hormones, but it is unknown whether these are a major source to the piglet. Piglets, like most mammalian neonates, possess very little adipose tissue at birth (1\% body weight; Mount 1968) and are, therefore, extremely sensitive to the decrease in environmental temperature $\left(15-20^{\circ} \mathrm{C}\right)$ experienced during the transition from the intra- to extra-uterine environment. This drop in ambient temperature results in a rapid fall in body temperature usually from 39 to $37^{\circ} \mathrm{C}$ (Herpin et al. 2002). 
In order to adapt to this large change in environmental temperature, most mammalian species possess brown adipose tissue (Nedergaard \& Cannon 1992); a tissue specialised for heat production via mitochondrial UCP1, which is unique to brown adipose tissue. However, pigs are one of the few species that are established to date to lack brown adipose tissue (Trayhurn et al. 1989). Consequently, piglets utilise other strategies of heat production and conservation, including muscular shivering, in order to maintain homeothermy. These alternative strategies require a good supply of nutrients to the piglet, in particular, lipids for skeletal muscle energy utilisation; milk is, therefore, key in providing lipid for this purpose (Le Dividich \& Noblet 1981).

Leptin is a $16 \mathrm{kDa}$ protein produced primarily in adipose tissue, which has roles in energy regulation and metabolism, food intake and reproduction (Pelleymounter et al. 1995, Scarpace et al. 1997, Cunningham et al. 1999). Leptin is also present in the milk of humans and lactating sows and appears to be related to maternal adiposity in the human, but not in the sow (Houseknecht et al. 1997, Estienne et al. 2000). Milkborne leptin may play a role in the maturation and development of the neonatal intestine (Wolinski et al. 2003). It is unknown whether leptin concentrations in sow's milk differ between commercial and Meishan breeds, which may in part explain differences in piglet physiology between the two breeds. Thyroxine $\left(T_{4}\right)$ and $T_{3}$ are both present in colostrum and milk at concentrations that vary between species (Akasha \& Anderson 1984). Thyroid hormones regulate energy metabolism by increasing respiration and energy expenditure and by lowering metabolic efficiency (Symonds et al. 1995) and exert their biological effects by promoting gene transcription (Bassett et al. 2003). A thyroid hormone deiodinating system exists in lactating mammary tissue of a number of species (Aceves \& Valverde 1989, Slebodzinski et al. 1999) and this is thought to cause the comparatively low $\mathrm{T}_{4}$ and high $\mathrm{T}_{3}$ concentrations observed in milk compared with the maternal circulation. The precise physiological role of thyroid hormones in milk is unknown and is unclear whether the amount received by the newborn is sufficient to cause any physiological effects.

Leptin is known to regulate and be regulated by a number of genes involved in growth and metabolism of adipose tissue, including insulin-like growth factor I (IGF-I), peroxisome proliferator activated receptor $\gamma(\operatorname{PPAR} \gamma)$ and glucocorticoid receptor (GR) (Gnanalingham et al. 2005, Kintscher \& Law 2005, Trayhurn 2005). We have previously observed significantly higher plasma IGF-I in commercial compared with Meishan piglets (A Mostyn \& JC Litten, unpublished observations; day 0 , commercial, $33 \cdot 2 \pm 6 \cdot 4$; Meishan, $19 \cdot 9 \pm 2.9 \mathrm{ng} / \mathrm{ml}(P<0 \cdot 05))$, it is not known whether these increased plasma concentrations are mirrored by adipose tissue expression of IGF-I or its binding protein, IGFBP-3. PPAR $\gamma$ ligands, thiazolidinediones (TZDs), reduce leptin mRNA expression in adipose tissue and also antagonises the transactivation of the leptin promoter (Hammarstedt et al. 2005). Both actions would reduce circulating leptin and action upon the leptin receptor. The GR is upregulated in vitro by chronic leptin administration, but is conversely downregulated following acute leptin administration (Gnanalingham et al. 2005). Breed differences in glucocorticoid activity have been observed in the placenta (Klemcke et al. 2003), brain, kidney and liver (Perreau et al. 1999) of Meishan and commercial pigs. Glucocorticoids have a key role in adipose tissue regulation, but the expression of GR in adipose tissue of Meishan and commercial piglets has not yet been explored.

The aim of this study was to investigate whether milkborne leptin and thyroid hormones $\left(T_{3}\right.$ and $\left.T_{4}\right)$ were differentially available in sow milk from two breeds of pig and whether the key adipose tissue genes were influenced by the availability of leptin or genotype. This study also aimed to establish the natural ontogeny of these hormones over the first 4 days of postnatal age in the milk of Meishan and commercial sows and relate these values to organ development and piglet growth parameters.

\section{Materials and Methods}

Eight Meishan and six commercial (Large White $(75 \%) \times$ Meishan (25\%)) sows of similar mating date and parity were entered into the study. At around $4 \mathrm{~h}$ after birth, all piglets in each litter were weighed and those closest to the median weight were assigned to be blood sampled daily. At approximately $0930 \mathrm{~h}$ each day, colonic temperature was measured with a digital thermometer, piglets were weighed and venous blood sample was taken (as described by Litten et al. 2005). Milk was manually sampled from each sow and immediately frozen at $-20^{\circ} \mathrm{C}$. On days 0 and 4 , morphometric measurements, including head circumference and crown to rump length (CRL), were made along with the measurement of total body electrical conductivity (TOBEC) as described previously (Mostyn et al. 2004). This is a non-invasive technique designed to estimate fatfree mass and thereby indirectly measures body fat in live animals (Bellinger \& Williams 1993). TOBEC values are computed using the following formula, which takes into account body size:

Lean mass $=\sqrt{ } \mathrm{TOBEC} \times \mathrm{CRL}$

On day 4, piglets were humanely euthanised with an overdose of barbiturate anaesthetic $(200 \mathrm{mg} / \mathrm{kg}$ pentobarbital sodium:euthatal; RMB Animal Health, UK). All tissues, including a reproducible sample of s.c. adipose tissue (SAT), were rapidly dissected, weighed and stored at $-80^{\circ} \mathrm{C}$ until further analysis. All operative procedures and experimental protocols had the required Home Office approval as designated by the Animals (Scientific Procedures) Act (1986). 


\section{Laboratory procedures}

Milk samples were thawed and the whole milk was used for all the assays.

Plasma concentrations of glucose (coefficient of variation, $\mathrm{CV}=5 \cdot 3 \%$ ), triacylglyceride (TAG; $\mathrm{CV}=6 \cdot 9 \%$; Sigma Chemical) and non-esterified fatty acids (NEFA; $\mathrm{CV}=$ 2.8\%; Wako NEFA-C; Alpha Labs) were determined enzymatically. Total plasma and milk $\mathrm{T}_{3}(\mathrm{CV}=4 \cdot 9)$, thyroxine $\left(\mathrm{T}_{4} ; \mathrm{CV}=8 \cdot 4\right)$ and leptin $(\mathrm{CV}=2 \cdot 6)$ concentrations were assessed using RIA (ICN Pharmaceuticals, Basingstoke, UK; leptin Linco, St Louis, MO, USA) as described previously by Litten et al. (2005).

\section{Molecular biology procedures}

Total RNA was extracted from SAT using the RNeasy kit (Qiagen Ltd) and was reverse transcribed (Moloney-murine leukaemia virus reverse transcriptase; Promega, UK). Realtime PCR was performed using a Quantica real-time thermocycler (Techne Incorporated, Barloworld Scientific Ltd, Stone, UK) with the Quantitect SYBR green PCR mix (Qiagen Ltd) in order to determine transcription levels of the following genes: IGF-I, IGFBP-3, PPAR $\gamma$ and GR. 18S rRNA was used as a housekeeping gene. PCR primer sequences are shown in Table 1. Gene expressions were measured by the $2^{-\Delta \mathrm{CT}}$ method (Livak \& Schmittgen 2001). Levels of gene expression were expressed as relative values using commercial pig values as a reference $(1 \cdot 0)$.

\section{Statistical analyses}

Power calculations using SamplePower 2 dictated that $n=6$ would have power of $92 \cdot 4 \%$ to yield a statistically significant result. All statistical evaluations were performed by using SPSS $11 \cdot 0$ for windows (SPSS Inc., Chicago, IL, USA) using the General Linear Model procedure with correction for repeated measures if appropriate and Spearman's $\rho$-test. All values presented are means with their standard errors.

\section{Results}

\section{Growth and morphology}

Meishan piglets were weighed significantly $(P<0 \cdot 05)$ lower than commercial piglets (Fig. 1a), this was combined with a higher number of siblings in Meishan litters (Meishan, $12 \cdot 8 \pm 0 \cdot 8$; commercial, $7 \cdot 8 \pm 1 \cdot 7$ piglets per litter; $P<0 \cdot 05)$. They also had a lower fat-free mass $(P<0 \cdot 05)$ on days 1 and 4 of the study indicating that they were fatter (Fig. 1b).

\section{Body composition}

As expected, there were a number of differences between absolute organ weights between the breeds (heart, lung, brain and liver) due to the differences in body weight. When organ weights were expressed per kilogram/body weight, on day 4 of postnatal age only the spleen was heavier $(P<0 \cdot 05)$ in the Meishan piglets (Fig. 1c).

\section{Plasma and milk hormones and metabolites}

There was a trend for leptin in milk to be higher in samples from commercial sows, although this was only statistically significant on day 3 of piglet postnatal age (Fig. 2a). When the mean leptin concentration in milk was considered, there was a significant difference between genotypes with commercial sows producing milk containing more than twofold leptin (Fig. 2b). Plasma leptin concentrations were unaffected by age and similar between Meishan and commercial piglets throughout the study (e.g. day 0; Meishan, $2 \cdot 0 \pm 0 \cdot 1$; commercial, $2 \cdot 0 \pm 0 \cdot 1 \mathrm{ng} / \mathrm{ml}$ ).

$\mathrm{T}_{3}$ concentrations were higher $(P<0 \cdot 05)$ in milk from Meishan compared with commercial sows (Fig. 3), although plasma $\mathrm{T}_{3}$ was similar between genotypes on all days of the study (e.g. day 3; Meishan, $1 \cdot 7 \pm 0 \cdot 2$; commercial, $1 \cdot 6 \pm$ $0 \cdot 4 \mathrm{ng} / \mathrm{ml})$. In contrast, plasma $\mathrm{T}_{4}$ concentrations were higher $(P<0 \cdot 05)$ in commercial compared with Meishan

Table 1 Primer sequences for genes used in real-time PCR

\begin{tabular}{|c|c|c|c|}
\hline & & Primer sequences & Product length $(\mathrm{bp})$ \\
\hline \multicolumn{4}{|l|}{ Gene } \\
\hline \multirow[t]{2}{*}{ IGF-I } & Forward & 5'-CTTCAGTTCGTGTGCGGAGAC-3' & 134 \\
\hline & Reverse & 5'-CTCCAGCСТССТCAGATCACAG-3' & \\
\hline \multirow[t]{2}{*}{$\operatorname{PPAR} \gamma$} & Forward & 5'-ACGGGAAAGACGACAGACAAATC-3' & 151 \\
\hline & Reverse & $5^{\prime}$-CACGGAGCGAAACTGACACC-3' & \\
\hline \multirow[t]{2}{*}{ IGFBP-3 } & Forward & 5'-CGGGTGCCTGACTCCAAACTC-3' & 122 \\
\hline & Reverse & 5'-GTTCTGGGTGTCCGTGCTCTG-3' & \\
\hline \multirow[t]{2}{*}{ GR } & Forward & 5'-GCTGCTGGTCCTGCTGCTC-3' & 82 \\
\hline & Reverse & 5'-ССТTСАСАТTСGGСТGСТСТGG-3' & \\
\hline \multirow[t]{2}{*}{$18 \mathrm{~S}$} & Forward & 5'-GATGCGGCGGCGTTATTCC-3' & 125 \\
\hline & Reverse & 5'-CTCCTGGTGGTGCCCTCC-3' & \\
\hline
\end{tabular}

IGF-I, insulin like growth factor I; PPAR $\gamma$, peroxisome proliferators activated receptor $\gamma$; UGF-BP3, insulin-like growth factorbinding protein 3; GR, glucocorticoid receptor; $18 \mathrm{~S}$, $18 \mathrm{~S}$ ribosomal RNA. 

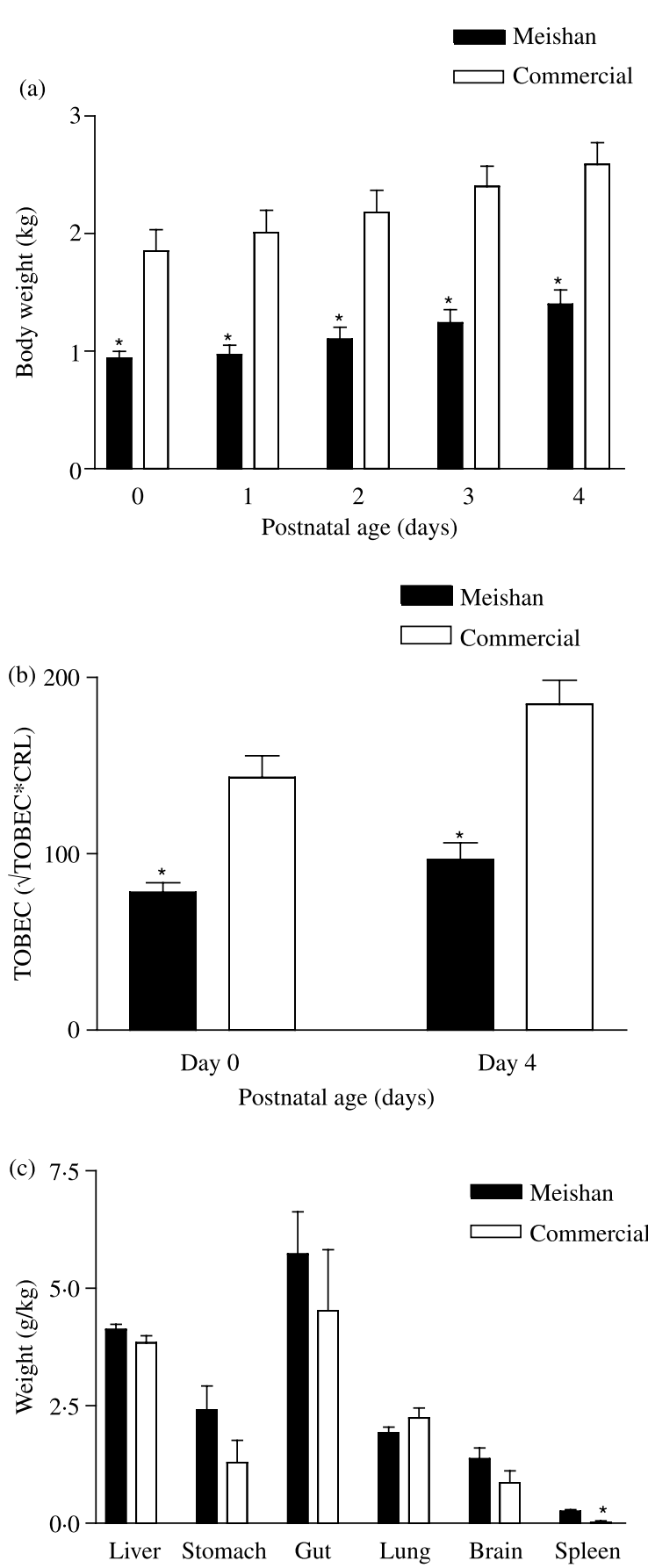

Figure 1 (a) Mean body weight (in kilogram) in Meishan ( $\mathbf{a}$ ) and commercial $(\square)$ piglets over the first 4 days of postnatal age. Values are means with their standard errors. Significant differences between breeds at the same postnatal age is denoted by $* P<0 \cdot 05$. (b) Mean TOBEC in Meishan ( $\mathbf{\square})$ and commercial $(\square)$ piglets over days 0 and 4 of postnatal age. Values are means with their standard errors. Significant differences between groups at the same postnatal age is denoted by $* P<0 \cdot 05$. (c) Body composition $(g / k g)$ in Meishan ( $\square$ ) and commercial ( $\square$ ) piglets on day 4 of postnatal age. Values are means with their standard errors. Significant differences between breeds at the same postnatal age is denoted by $* P<0 \cdot 05$. piglets on all days for the study (Fig. 4). There were no significant differences in milk $\mathrm{T}_{4}$ concentrations (e.g. day 1 ; Meishan, $15 \cdot 3 \pm 0 \cdot 6$; commercial, $15 \cdot 9 \pm 2 \cdot 2 \mathrm{ng} / \mathrm{ml}$ ).

Plasma glucose was found to increase in both genotypes during the study and was significantly higher in commercial piglets only on day 1 of postnatal age (Meishan, $5 \cdot 0 \pm 0 \cdot 2$; commercial, $6 \cdot 8 \pm 0.6 \mathrm{mM}(P<0 \cdot 05))$. There were no significant differences in plasma NEFA or TAG between the genotypes during the study (data not shown).

A number of significant relationships were observed between the milk hormones and the plasma hormones and metabolites. Milk leptin was positively associated with plasma leptin in the Meishan group on days 0 and 1 of postnatal age, but on day 2 this relationship was reversed; thereafter, milk leptin was no longer associated with piglet plasma leptin concentrations (Table 2). On days 1 and 2 of postnatal age, milk leptin was significantly positively associated with plasma glucose levels in commercial piglets alone (Table 2); by day 3, this relationship had reversed (Table 2).
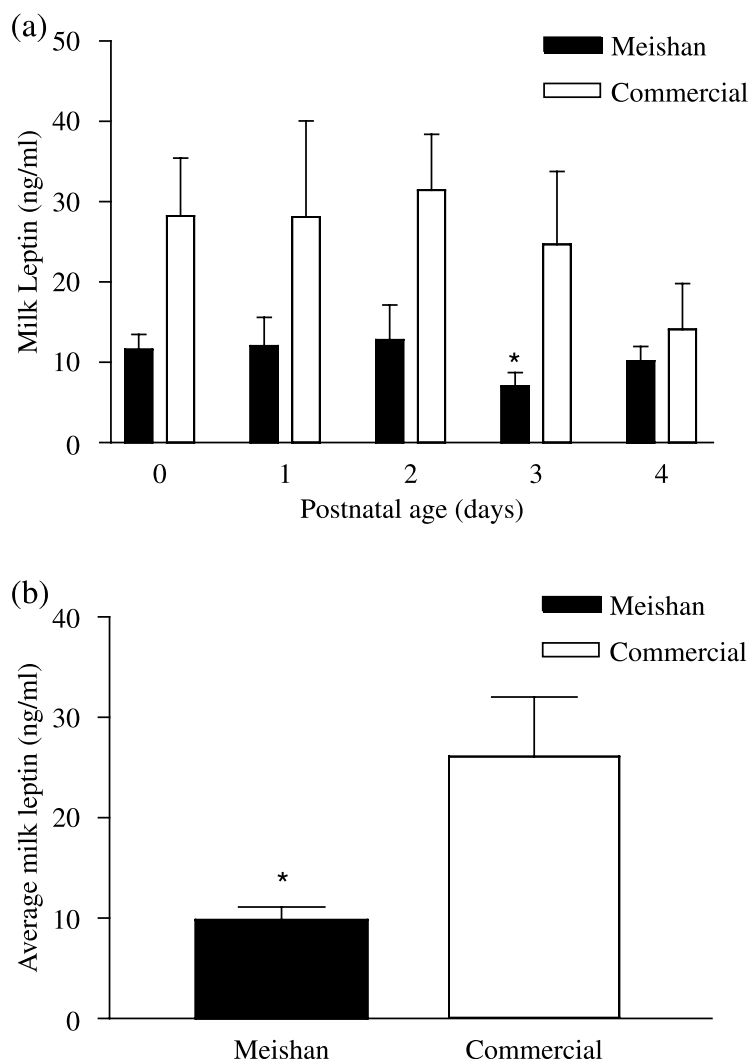

Figure 2 (a) Milk leptin concentrations in Meishan ( $\boldsymbol{\square}$ ) and commercial ( $\square$ ) piglets over the first 4 days of postnatal age. Values are means with their standard errors. Significant differences between breeds at the same postnatal age is denoted by $* P<0 \cdot 05$. (b) Average milk leptin concentrations in Meishan ( $\square$ ) and commercial $(\square)$ piglets over the first 4 days of postnatal age. Values are means with their standard errors. Significant differences between breeds at the same postnatal age is denoted by $* P<0 \cdot 05$. 


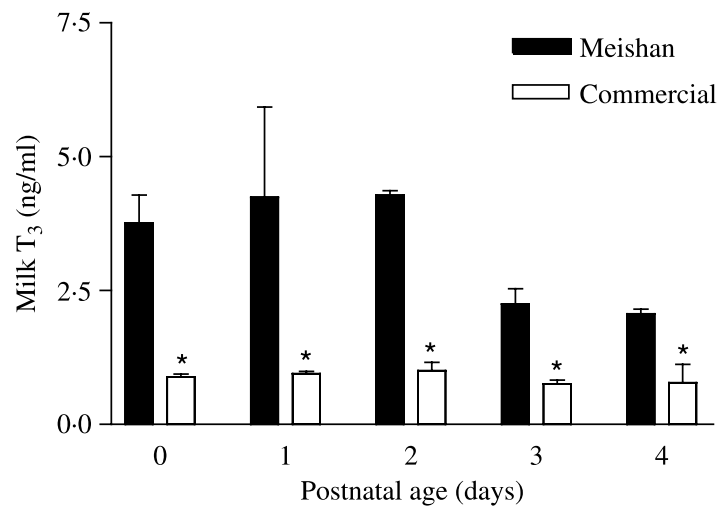

Figure 3 Sow milk $T_{3}$ concentrations in Meishan ( $\boldsymbol{\square}$ ) and commercial ( $\square$ ) piglets over the first 4 days of postnatal age. Values are means with their standard errors. Significant differences between breeds at the same postnatal age is denoted by ${ }^{*} P<0 \cdot 05$.

The average milk concentration of leptin in sow milk over the study period was found to be significantly positively related to body weight, girth and growth rate, as well as gut, heart and spleen weight in Meishan piglets (Table 3). No growth parameters were associated with average milk leptin in the commercial piglets, although there was a significant positive relationship between lung weight and average plasma leptin $\left(R^{2}=0 \cdot 68, P<0 \cdot 05\right)$.

\section{Gene expression of IGF-I, IGFBP-3, PPAR $\gamma$ and GR}

There were no differences in IGF-I, IGFBP-3 or PPAR $\gamma$ gene expression in SAT of Meishan and commercial piglets on 4 days of age (Fig. 5; IGFBP-3 not shown). However, GR was significantly upregulated in SAT of Meishan piglets (Fig. 5). A significantly positive relationship was found between GR and day 4 TOBEC $\left(R^{2}=0 \cdot 79, \quad y=4 \times 10^{-7} x+1 \times 10^{-5}\right.$; $P<0 \cdot 05)$ in Meishan piglets.

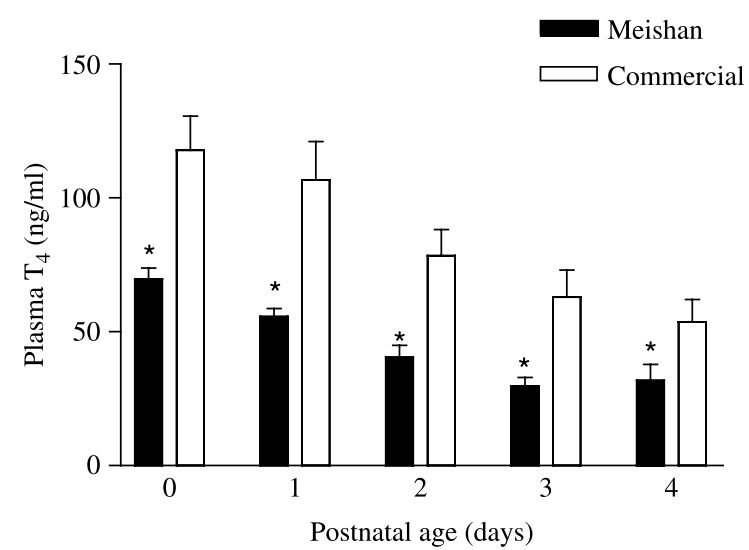

Figure 4 Plasma $\mathrm{T}_{4}$ concentrations in Meishan ( $)$ and commercial ( $\square$ ) piglets over the first 4 days of postnatal age. Values are means with their standard errors. Significant differences between breeds at the same postnatal age is denoted by $* P<0 \cdot 05$.

\section{Discussion}

Our study has demonstrated for the first time a significant disparity in the provision of leptin and $\mathrm{T}_{3}$ in milk from Meishan and commercial sows. Plasma concentrations of the respective hormones in piglets remained similar between breeds, despite this there were potential effects on organ and body growth between breeds. The differences in growth and adiposity of the piglet genotypes may be attributed to disparity in adipose tissue GR expression.

\section{Leptin in sows milk}

A role for leptin in maternal milk has yet to be defined, but may be involved in maturation of the small intestine or neonatal growth (Wolinski et al. 2003). These authors have demonstrated that piglets fed with milk formula had delayed small intestine mucosal development compared with feeding with sow's milk. Importantly, this effect could be reversed when the formula was supplemented with exogenous leptin (Wolinski et al. 2003). Interestingly, a strong positive relationship between gut weight and average milk leptin was observed in the Meishan piglets in this study (Table 3). Studies by Casabiell et al. (1997) have shown, in the rat, that leptin passes through the pups' digestive system in its intact form and can be detected in neonatal serum. Average milk leptin was positively related to piglet growth rate, girth, body, gut, heart and spleen weight in the Meishan group only, suggesting a growth promoting effect of milk-derived leptin. The positive relationship between spleen weight and leptin may represent an immunological effect. Leptin treatment has been suggested to increase proliferation of splenocytes and improve immune function after starvation (Mito et al. 2004); however, this would require further investigation. The present results complement the previous work, which found that chronic (6 days) leptin treatment of newborn piglets improved growth rate and altered body composition in the Meishan (Litten et al. 2005). From the present data, it seems unlikely that leptin from maternal milk has a large influence on neonatal plasma leptin concentrations, but may act to specifically promote tissue and body growth.

Previous studies have demonstrated that leptin is found at significantly higher concentrations in sows milk compared with the circulation (Estienne et al. 2000). This is in contrast to human milk, which contains leptin at a significantly lower concentration than that of maternal plasma (Houseknecht et al. 1997). In the human, specific hormones and growth factors, e.g. prolactin are concentrated in milk by the breast but leptin does not appear to be under the same regulation, this could be different in the pig. It is more likely that local production accounts for a high percentage of the leptin in sow's milk given that the concentrations are much higher than those found in maternal plasma (i.e. two- to sixfold higher depending on breed). The breast is composed of a high percentage of adipose tissue and it is possible that this depot 
Table 2 Significant associations between milk and plasma hormones in measured during the study

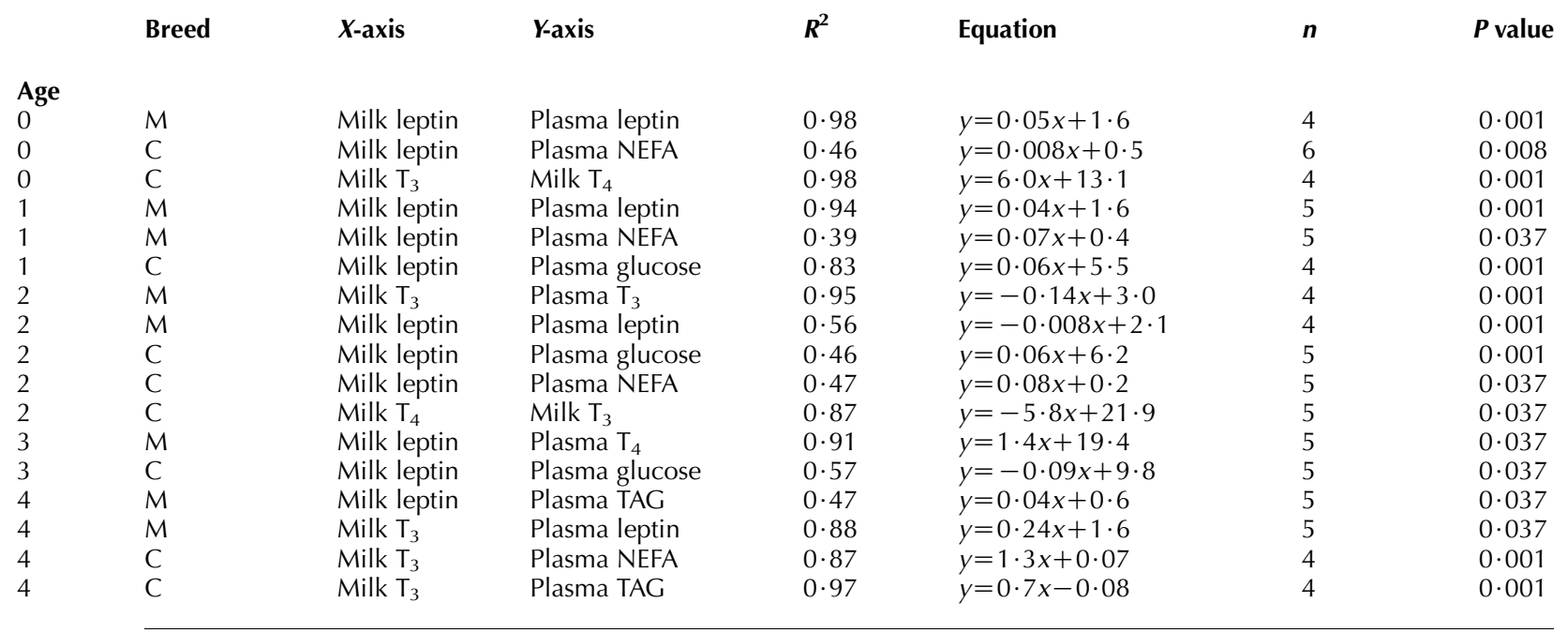

NEFA, non-esterified fatty acids; $T_{3}$, triiodothyronine; $T_{4}$, thyroxine; TAG, triacylglycerol; $M$, Meishan; $C$, commercial.

provides a source of leptin; alternatively, studies have demonstrated that human mammary epithelial cells produce leptin (Smith-Kirwin et al. 1998). One further explanation for the high levels of leptin observed in sow's milk could be a lack of leptin-binding protein. A portion of leptin found in the circulation exists bound to a short form of the leptin receptor thought to be a binding protein (Huang et al. 2001). Although the long- and short-form of the leptin receptor are present in mammary tissue in a number of species (Laud et al. 1999), it is unknown if the binding protein is secreted into milk.

The concentration of leptin in sows milk were three- to tenfold higher than piglet plasma depending on genotype in this study. Estienne et al. (2000) reported leptin plasma concentrations of $3 \cdot 7 \pm 2 \mathrm{ng} / \mathrm{ml}$ in lactating sows; these are comparable to concentrations taken previously in lactating commercial sows in our unit $(5.5 \mathrm{ng} / \mathrm{ml}$ within $24 \mathrm{~h}$ parturition). The role of leptin in sows milk may, therefore, be different from that of human milk. A number of studies have found no link between sow milk leptin concentrations and body composition/weight or sow plasma concentrations (Estienne et al. 2000) suggesting that the milk concentration of leptin in pigs is not indicative of body composition nor fat content. In the present study, there was a strong trend for the concentration of leptin in milk to be higher in commercial sows (Fig. 2a and b), despite commercial sows being considerably leaner than the obese Meishan sows, in accordance with previous studies.

Despite a twofold greater concentration of leptin in commercial sow milk, there was no difference between circulating leptin levels in the offspring, suggesting that either leptin is broken down (a) from its intact form in the stomach, or does not pass through the gut wall or (b) through first pass metabolism in the pig in contrast to the rat (Casabiell et al. 1997). However, leptin receptors do exist in the stomach and it is possible that part of the relationships observed between milk leptin and metabolites may be due to leptins' action through these receptors (Mix et al. 2000).

\section{Thyroid hormones in sows milk}

A number of studies have demonstrated the presence of thyroid hormones in human maternal milk at varying concentrations $\left(\mathrm{T}_{4} 0-77 \mathrm{ng} / \mathrm{ml}, \mathrm{T}_{3} 0 \cdot 1-4 \mathrm{ng} / \mathrm{ml}\right.$; Mizuta et al. 1983, van Wassenaer et al. 2002) that are comparable to

Table 3 Significant associations (all positive) between the mean milk leptin concentration ( $X$-axis) over the first 4 days of postnatal age and growth and organ weights taken on day 4 of postnatal age in Meishan piglets

\begin{tabular}{|c|c|c|c|c|}
\hline & $R^{2}$ & Equation & $n$ & $P$ value \\
\hline \multicolumn{5}{|l|}{ Y-axis } \\
\hline Body weight & $0 \cdot 78$ & $y=0.08 x+0 \cdot 6$ & 7 & $0 \cdot 014$ \\
\hline Growth rate & $0 \cdot 74$ & $y=0.009 x-0.006$ & 6 & $0 \cdot 036$ \\
\hline Girth & $0 \cdot 84$ & $y=1 \cdot 5 x-26 \cdot 3$ & 7 & $0 \cdot 019$ \\
\hline Gut weight & $0 \cdot 86$ & $y=5 \cdot 4 x+40 \cdot 1$ & 7 & $0 \cdot 007$ \\
\hline Heart weight & $0 \cdot 86$ & $y=0 \cdot 8 x+2 \cdot 9$ & 7 & $0 \cdot 023$ \\
\hline Spleen weight & 0.66 & $y=0 \cdot 3 x+1 \cdot 2$ & 7 & $0 \cdot 016$ \\
\hline
\end{tabular}


(a)

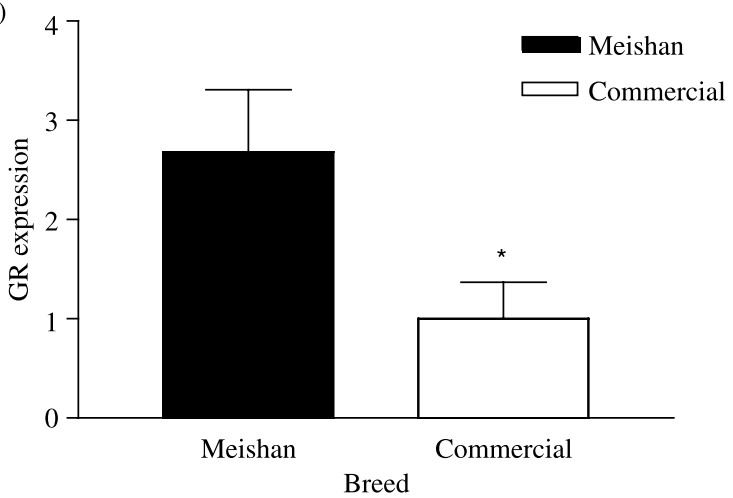

(b)
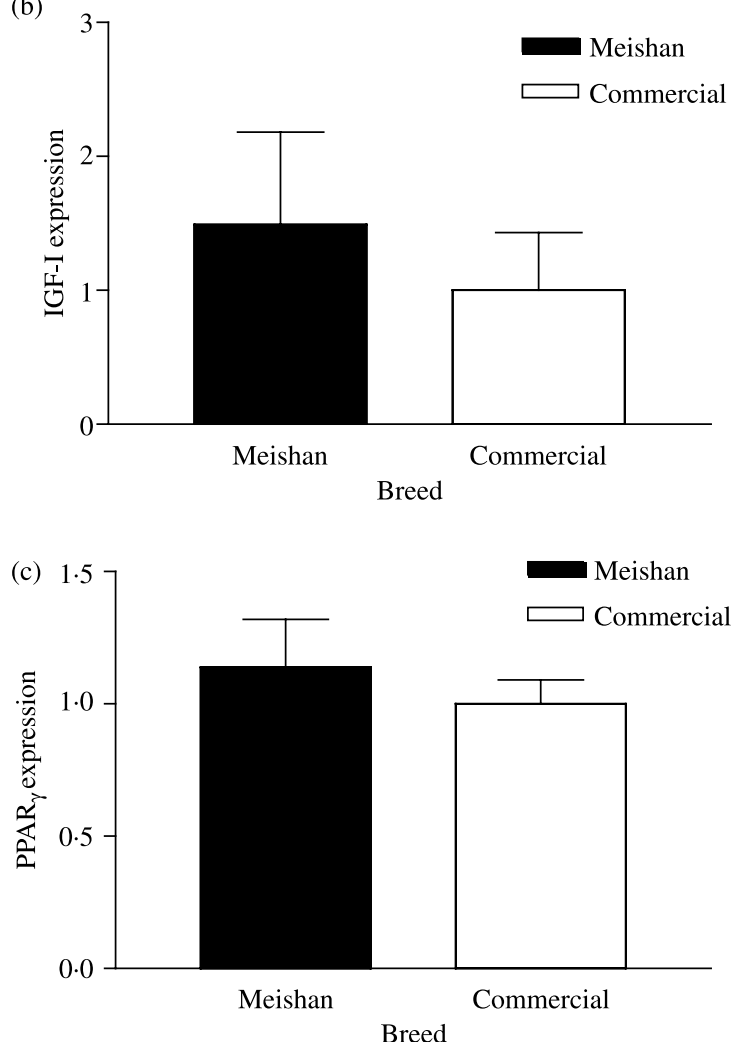

Figure 5 (a) Glucocorticoid receptor (GR) expression in adipose tissue from Meishan $(\boldsymbol{\square})$ and commercial $(\square)$ piglets on day 4 of postnatal age. Values are means with their standard errors.

Significant difference between breeds at the same postnatal age is denoted by $* P<0 \cdot 05$. (b) Insulin-like growth factor I (IGF-I) expression in adipose tissue from Meishan $(\boldsymbol{\square})$ and commercial $(\square)$ piglets on day 4 of postnatal age. Values are means with their standard errors. (c) Peroxisome proliferator activated receptor $\gamma$ $($ PPAR $\gamma$ ) expression in adipose tissue from Meishan ( $\boldsymbol{\square})$ and commercial $(\square)$ piglets on day 4 of postnatal age. Values are means with their standard errors. those measured in the pig in the present study. $T_{3}$ was elevated in Meishan compared with commercial sows' milk, although a similar trend in piglet plasma $\mathrm{T}_{3}$ was not observed. Although the significantly higher concentration of $\mathrm{T}_{3}$ in Meishan milk did not appear to influence piglet plasma concentrations of $\mathrm{T}_{3}$; it may have had a negative effect of plasma $\mathrm{T}_{4}$, which was considerably reduced in Meishan compared with commercial piglets throughout the study.

The higher milk $\mathrm{T}_{3}$ concentration observed in Meishan sows was unexpected as these sows have considerably more body fat than commercial sows and as such would be expected to have lower circulating $\mathrm{T}_{3}$. However, there was no difference, in the plasma $\mathrm{T}_{3}$ concentrations of piglets. This raises two questions: (i) do milk thyroid hormone levels reflect maternal circulating concentrations? and (ii) what is happening to the high concentrations of $\mathrm{T}_{3}$ provided to the Meishan piglets that is not observed in neonatal plasma? It seems likely that milk thyroid concentrations do not reflect maternal circulating levels; it has been demonstrated in lactating cows that the highest concentrations of $\mathrm{T}_{3}$ in colostrum coincided with the lowest maternal plasma concentrations (Pezzi et al. 2003), and could be important in improving neonatal outcome (Symonds et al. 1989). Thyroid hormones can pass through the digestive system in their intact active form, suggesting that digestion is not causing the discrepancy between milk and plasma concentrations, and it is possible that $T_{3}$ is being bound to thyroidbinding protein. Only negative relationships between milk $\mathrm{T}_{3}$ and plasma thyroid hormones were observed, confirming that the milk concentrations were not increasing plasma concentrations in piglets.

Thyroxine deiodinases are known to be present in the mammary gland of lactating sows (Slebodzinski et al. 1999), which is responsible for mammary production of $T_{3} . T_{4}$ was present at a very low concentration in milk when compared with the levels of $\mathrm{T}_{3}$, which were similar to those observed in plasma (Figs 2 and 3), suggesting that deiodination was taking place.

Interestingly, the differences observed in plasma $T_{3}$ between Meishan and commercial piglets on day 0 in a previous study (Mostyn et al. 2004) were not apparent. A potential reason for this disparity was that the maternal diet was different in the present study. A commercially available diet suitable for lactating sows (ABN Supreme Lactation Pellets, ABN, Peterborough, UK) was provided to all pigs on the trial. The components of this diet had been modified to include extra phytase. Phytic acid is known to inhibit absorption of trace minerals (such as zinc) from the diet (Hurrell 2003). Zinc allows $\mathrm{T}_{4}$ to enter cells and be converted into $\mathrm{T}_{3}$ thus stimulating thyroid production; treatment with zinc causes an increase in both free and total plasma $T_{3}$ (Baltaci et al. 2004). These dietary changes could have influenced thyroid hormones in the sows and consequently, placental availability of thyroid hormones may have been altered during gestation leading to the discrepancy with the previous study (Mostyn et al. 2004). 
Milk $\mathrm{T}_{3}$ was strongly positively correlated with the lipid metabolites, NEFA and TAG on day 4 in the commercial group only, suggesting that this source of $\mathrm{T}_{3}$ is beginning to act in a 'traditional' way, i.e. oxidation of lipids. This was not apparent in the Meishan group, thus it may be one of the mechanisms, which allow Meishan piglets to lay down vast amounts of adipose tissue during the postnatal period; alternatively, this may represent a potential 'sparing' of lipid stores, which relates to the increased neonatal survival rates observed in this breed.

\section{Adipose tissue gene expression}

The expression of PPAR $\gamma$, IGF-I and IGFBP-1 were found to be similar between the piglet genotypes. However, the significantly higher GR in Meishan adipose tissue may be the key to increase adiposity in this breed. Previous work has demonstrated that Meishan pigs have significantly higher plasma cortisol concentrations (Mormede et al. 1984, Sutherland et al. 2005) when compared with leaner, commercial breeds, such as Landrace and Yorkshire. These studies were investigating the role of stress and immune competency on cortisol concentrations and not adipose tissue regulation. Moreover, a study of dexamethasone perfusion during pregnancy in rat induced small birth weight offspring associated with GR upregulation in adipose tissue (Cleasby et al. 2003). These previous observations suggest that the differential cortisol levels in Meishan and commercial sows could program adipose tissue GR expression and fat mass growth. The strong relationship between GR and TOBEC on day 4 suggests that increased GR expression, which would promote lipid storage, along with the lower concentrations of maternally derived leptin, which would compel the piglet to feed, may be driving the increased adiposity observed in the Meishan piglets.

In conclusion, we have found a significant discrepancy between the provision of thyroid hormones and leptin found in Meishan and commercial sow's milk. These changes do not appear to be translated to piglet circulating concentrations of hormones. Milk-derived $\mathrm{T}_{3}$ and leptin regulate piglet plasma hormones and metabolites, but only leptin appears to be linked to organ and body growth. The benefit of milk-derived leptin and thyroid hormones remains to be established.

\section{Acknowledgements}

This work was supported by Biotechnology and Biological Sciences Research Council Grant S15331 and J C Litten was funded by a Wye College Studentship. S Sebert was funded by the European Union Sixth Framework Programme for Research and Technical Development of the European Community - The Early Nutrition Programming Project (FOOD-CT-2005-007036). The authors declare that there is no conflict of interest that would prejudice the impartiality of this scientific work.

\section{References}

Aceves C \& Valverde C 1989 Type I, 5'-monodeiodinase activity in the lactating mammary gland. Endocrinology 124 2818-2820.

Akasha M \& Anderson RR 1984 Thyroxine and triiodothyronine in milk of cows, goats, sheep, and guinea pigs. Proceedings of the Society for Experimental Biology and Medicine 177 360-371.

Alston-Mills B, Iverson SJ \& Thompson MP 2000 A comparison of the composition of milks from meishan and crossbred pigs. Livestock Production Science 63 85-91.

Baltaci AK, Mogulkoc R, Kul A, Bediz CS \& Ugur A 2004 Opposite effects of zinc and melatonin on thyroid hormones in rats. Toxicology 195 69-75.

Bassett JHD, Harvey CB \& Williams GR 2003 Mechanisms of thyroid hormone receptor-specific nuclear and extra nuclear actions. Molecular and Cellular Endocrinology 213 1-11.

Bellinger LL \& Williams FE 1993 Validation study of a total body electrical conductive (TOBEC) instrument that measures fat-free body mass. Physiology and Behaviour 53 1189-1194.

Casabiell X, Pineiro V, Tome MA, Peino R, Dieguez C \& Casanueva FF 1997 Presence of leptin in colostrum and/or breast milk from lactating mothers: a potential role in the regulation of neonatal food intake. Journal of Clinical Endocrinology and Metabolism 82 4270-4273.

Cleasby ME, Kelly PA, Walker BR \& Seckl JR 2003 Programming of rat muscle and fat metabolism by in utero overexposure to glucocorticoids. Endocrinology 114 999-1007.

Cunningham MJ, Clifton DK \& Steiner RA 1999 Leptin's actions on the reproductive axis: perspectives and mechanisms. Biology of Reproduction 60 216-222.

Estienne MJ, Harper AF, Barb CR \& Azain MJ 2000 Concentrations of leptin in serum and milk collected from lactating sows differing in body condition. Domestic Animal Endocrinology 19 275-280.

Gnanalingham MG, Mostyn A, Webb R, Keisler DH, Raver N, Alves-Guerra M, Pecqueur C, Miroux B, Symonds ME \& Stephenson T 2005 Differential effects of leptin administration on the abundance of uncoupling protein-2 and glucocorticoid action during neonatal development. American Journal of Physiology 289 E1093-E1100.

Hammarstedt A, Andersson CX, Rotter Sopasakis V \& Smith U 2005 The effect of PPAR $\gamma$ ligands on the adipose tissue in insulin resistance. $3 r d$ Throne Holst Foundation Symposium 73 65-75.

Herpin P, Le Dividich J \& Amaral N 1993 Effect of selection for lean tissue growth on body composition and physiological state of the pig at birth. Journal of Animal Science 71 2645-2652.

Herpin P, Damon M \& Le Dividich J 2002 Development of thermoregulation and neonatal survival in pigs. Livestock Production Science 78 25-45.

Houseknecht KL, McGuire MK, Portocarrero CP, McGuire MA \& Beerman K 1997 Leptin is present in human milk and is related to maternal plasma leptin concentration and adiposity. Biochemical and Biophysical Research Communications 240 742-747.

Huang L, Wang Z \& Li C 2001 Modulation of circulating leptin levels by its soluble receptor. Journal of Biological Chemistry 276 6343-6349.

Hurrell RF 2003 Influence of vegetable protein sources on trace element and mineral bioavailability. Journal of Nutrition 133 2973S-2977S.

Kintscher U \& Law RE 2005 PPAR $\gamma$-mediated insulin sensitization: the importance offat versus muscle. American Journal of Physiology 288 E287-E291.

Klemcke HG, Sampath Kumar R, Yang K, Vallet JL \& Christenson RK 2003 $11 \beta$-Hydroxysteroid dehydrogenase and glucocorticoid receptor messenger RNA expression in porcine placentae: effects of stage of gestation, breed, and uterine environment. Biology of Reproduction 69 1945-1950.

Laud K, Gourdou I, Belair L, Keisler DH \& Djiane J 1999 Detection and regulation of leptin receptor mRNA in ovine mammary epithelial cells during pregnancy and lactation. FEBS Letters 463 194-198.

Le Dividich J \& Noblet J 1981 Colostrum intake and thermoregulation in the neonatal pig in relation to environmental temperature. Biology of the Neonate 40 167-174.

Le Dividich J, Mormede P, Catheline M \& Caritez JC 1991 Body composition and cold resistance of the neonatal pig from European (Large White) and Chinese (Meishan) breeds. Biology of the Neonate 59 268-277. 
Litten JC, Mostyn A, Perkins KS, Corson AM, Symonds ME \& Clarke L 2005 Effect of administration of recombinant human leptin during the neonatal period on the plasma concentration and gene expression of leptin in the piglet. Biology of the Neonate 87 1-7.

Livak KJ \& Schmittgen TD 2001 Analysis of relative gene expression data using real-time quantitative PCR and the $2^{-\Delta \Delta C T}$ method. Methods 25 402-408.

Mito N, Yoshino H, Hosoda T \& Sato K 2004 Analysis of the effect of leptin on immune function in vivo using diet-induced obese mice. Journal of Endocrinology 180 167-173.

Mix H, Widjaja A, Jandl O, Cornberg M, Kaul A, Goke M, Beil W, Kuske M, Brabant G, Manns MP et al. 2000 Expression of leptin and leptin receptor isoforms in the human stomach. Gut 47 481-486.

Mizuta H, Amino N, Ichihara K, Harada T, Nose O, Tanizawa O \& Miyai K 1983 Thyroid hormones in human milk and their influence on thyroid function of breast-fed babies. Pediatric Research 17 468-471.

Mormede P, Danzter R, Bluthe RM \& Caritez JC 1984 Differences in adaptive abilities of 3 breeds of Chinese pigs behavioural and neuroendocrine studies. Genetique, Selection, Evolution 16 85-102.

Mostyn A, Litten JC, Perkins KS, Alves-Guerra M, Pecqueur C, Miroux B, Symonds ME \& Clarke L 2004 Influence of genotype on the differential ontogeny of uncoupling protein 2 and 3 in subcutaneous adipose tissue and muscle in neonatal pigs. Journal of Endocrinology 183 121-131.

Mount LE 1968 In The Climatic Physiology of the Pig, Ed. LE Mount. London: Edward Arnold.

Nedergaard J \& Cannon B 1992 The uncoupling protein thermogenin and mitochondrial thermogenesis. In New Comprehensive Biochemistry, pp 385419. Ed. L Ernster. Amsterdam: Elsevier Science Publishers.

Norcross NL 1982 Secretion and composition of colostrum and milk. Journal of the American Veterinary Medical Association 181 1057-1060.

Pelleymounter MA, Cullen MJ, Baker MB, Hecht R, Winters D, Boone T \& Collins F 1995 Effects of obese gene product on body weight regulation in ob/ob mice. Science $269540-543$.

Perreau V, Sarrieau A \& Mormede P 1999 Characterization of mineralocorticoid and glucocorticoid receptors in pigs: comparison of Meishan and large white breeds. Life Sciences 64 1501-1515.

Pezzi C, Accorsi PA, Vigo D, Govoni N \& Gaiani R 2003 5'-Deiodinase activity and circulating thyronines in lactating cows. Journal of Dairy Science 86 152-158.
Scarpace PJ, Matheny M, Pollock BH \& Tumer N 1997 Leptin increases uncoupling protein expression and energy expenditure. American Journal of Physiology 273 E226-E230.

Slebodzinski AB, Brzezinska-Slebodzinska E, Styczynska E \& Szejnoga M 1999 Presence of thyroxine deiodinases in mammary gland: possible modulation of the enzyme-deiodinating activity by somatotropin. Domestic Animal Endocrinology 17 161-169.

Smith-Kirwin SM, O'Connor DM, Johnston J, de Lancy E, Hassink SG \& Funanage VL 1998 Leptin expression in human mammary epithelial cells and breast milk. Journal of Clinical Endocrinology and Metabolism 831810.

Sutherland MA, Rodriguez-Zas SL, Ellis M \& Salak-Johnson JL 2005 Breed and age affect baseline immune traits, cortisol, and performance in growing pigs. Journal of Animal Science 83 2087-2095.

Symonds ME, Andrews DC \& Johnson P 1989 The control of thermoregulation in the developing lamb during slow wave sleep. Journal of Developmental Physiology 11 289-298.

Symonds ME, Bird JA, Clarke L, Gate J \& Lomax MA 1995 Nutrition, temperature and homeostasis during perinatal development. Experimental Physiology 80 907-940.

Trayhurn P 2005 Endocrine and signalling role of adipose tissue: new perspectives on fat. Acta Physiologica Scandinavica 184 285-293.

Trayhurn P, Temple NJ \& Van Aerde J 1989 Evidence from immunoblotting studies on uncoupling protein that brown adipose tissue is not present in the domestic pig. Canadian Journal of Physiology and Pharmacology 67 1480-1485.

van Wassenaer AG, Stulp MR, Valianpour F, Tamminga P, Stalpers CR, de Randamie JSE, van Beusekom C \& de Vijlder JJM 2002 The quality of thyroid hormone in human milk is too low to influence plasma thyroid hormones levels in the very preterm infant. Clinical Endocrinology 56 621-627.

Wolinski J, Biernat M, Guilloteau P, Westrom BR \& Zabielski R 2003 Exogenous leptin controls the development of the small intestine in neonatal pigs. Journal of Endocrinology 177 215-222.

Received in final form 15 May 2006

Accepted 26 May 2006

Made available online as an Accepted Preprint 11 July 2006 